\title{
UJI EFEK ANTIBAKTERI JAMUR ENDOSIMBION SPONS LAUT Callyspongia sp. TERHADAP BAKTERI Pseudomonas aeruginosa dan Eschericia coli
}

\author{
Frengki P. Menggelea \\ Jimmy Posangi \\ Mona P. Wowor \\ Robert Bara
}

\author{
${ }^{1}$ Kandidat Skripsi Fakultas Kedokteran Universitas Sam Ratulangi Manado \\ ${ }^{2}$ Bagian Farmakologi dan Terapi Fakultas Kedokteran Universitas Sam Ratulangi Manado \\ Email: fmenggelea11_287@ymail.com
}

\begin{abstract}
Callyspongia sp. is one of the kinds of sea sponge which is hardly used instead of its potential in order to be used as antibacterial, anticancer, and also antifungi.The objective of the research is to observe the effect of antibacterial of endosymbiont fungi of Callyspongia sp. to Pseudomonas aeruginosa and Ecshericia coli. Method: Method chosen in order to test the antibacterial effect is by pasting the myselia of endosymbiont fungi on the subject. The result of the combination, then, is observed as a measure of zone of resistance in endosymbiont fungi test effect. Result: The result of the observation presents two kinds of endosymbiont fungi, isolated from the sea sponge Callyspongia; Black Myselium Fungi and Brown Myselium. The diameter's average of zone of resistance in Brown Myselium Endosymbiont Fungi to Pseudomonas aeruginosa is $16,8 \mathrm{~mm}$; the same amount gained to Eschericia coli, while the Black Myselium presents no zone of resistance. Conclusion: Brown Myselium Endosymbiont Fungi has the ability to resist the growth of Pseudomonas aeruginosa and Eschericia coli.

Keywords: antibacterial, endosymbiont fungi, Callyspongia sp. sea sponge.)
\end{abstract}

\begin{abstract}
Abstrak: Callyspongia sp. merupakan salah satu jenis spons yang berpotensi sebagai antibakteri, antikanker, dan antijamur yang belum banyak dimanfaatkan. Tujuan: untuk mengetahui ada tidaknya efek antibakteri jamur endosimbion spons laut Callyspongia sp. terhadap bakteri Pseudomonas aeruginosa dan Eschericia coli. Metode: Metode yang digunakan untuk uji antibakteri yaitu dilakukan dengan cara menempelkan miselia jamur endosimbion pada media agar kombinasi yang telah dioleskan bakteri uji untuk mengamati dan mengukur zona hambat yang dihasilkan jamur endosimbion. Hasil: Dari penelitian yang dilakukan, diperoleh dua jenis jamur endosimbion yang diisolasi dari spons laut Callyspongia sp., jamur endosimbion miselium hitam dan jamur endosimbion miselium coklat. Rata-rata diameter zona hambat jamur endosimbion coklat terhadap bakteri Pseudomonas aeruginosa 16,8 mm dan terhadap Eschericia coli 16,8 mm, sedangkan jamur endosimbion hitam tidak memiliki zona hambat. Simpulan: Jamur endosimbion coklat memiliki aktivitas menghambat pertumbuhan bakteri Pseudomonas aeruginosa dan Eschericia coli.
\end{abstract}

Kata kunci: antibakteri, jamur endosimbion, spons laut Callyspongia sp.

Sebagai negara kepulauan, Indonesia memiliki sumber daya alam hayati laut yang besar.Salah satu sumber daya alam tersebut yaitu ekosistem terumbu karang.
Di dalam ekosistem terumbu karang bisa hidup lebih dari300 spesies karang, lebih dari 200 spesies ikan dan ratusan spesies moluska,krustasea, spons, alga, lamun dan 
biota lainnya. Spons merupakan salah satu komponen penyusun terumbu karang yang mempunyai potensi bioaktif sebagai antibakteri, antikanker, dan antijamur yang belum banyak dimanfaatkan. ${ }^{1}$

Spons merupakan salah satu kelompok biota laut yang terdapat di perairan Indonesia dengan jumlah 850 spesies dan berpotensi menghasilkan senyawa metabolit sekunder yang bersifat bioaktif. Spons ialah hewan berpori yang bersifat filter feeder, karena sifat itulah sehingga biota menjadi habitat bagi mikroorganisme untuk tinggal dalam tubuhnya. ${ }^{2}$

Callyspongia sp. merupakan salah satu jenis spons yang banyak tumbuh di perairan Indonesia. Spesies ini merupakan salah satu biota laut yang memiliki kandungan berbagai metabolit sekunder diantaranya steroid, alkaloid, flavonoid, dan terpenoid yang nantinya dapat dimanfaatkan sebagai bahan baku obat. ${ }^{3}$

Simbiosis mikroba dengan spons dapat berlangsung di dalam sitoplasma sel tubuh spons (simbiosis intraseluler), di sisi dalam tubuh spons (endosimbiosis ekstraseluler), dan di bagian luar tubuh spons (eksosimbiosis ekstraseluler). ${ }^{4,5}$

Eschericia coli adalah flora normal yang terdapat pada saluran pencernaan, namun pada saat jumlahnya meningkat dari normalnya dan ada pada daerah yang normalnya tidak ada maka dapat menyebabkan infeksi, contohnya apabila bakteri Eschericia coli masuk ke dalam saluran kandung kemih, maka akan menyebabkan sistitis. ${ }^{7} \quad$ Pseudomonas aeruginosa dapat berada dalam tubuh manusia yang sistem imunnya normal, dan bakteri ini bersifat saprofit. Bersifat saprofit artinya bakteri ini dapat menyebabkan penyakit apabila sistem imunitas tubuh inangnya turun. ${ }^{8}$

\section{METODE PENELITIAN}

Penelitian ini dilaksanakan menggunakan metode eksperimental. Penelitian berlangsung sejak bulan September 2014 sampai Januari 2015. Penelitian dilaksanakan di Laboratorium Farmakologi dan Terapi Fakultas Kedokteran Universitas Sam Ratulangi Manado.

\section{Alat dan Bahan}

Alat-alat yang digunakan dalam penelitian ini yaitu: cawan petri, tabung reaksi, pinset, kapas lidi steril, oven, inkubator, api bunsen, jarum ose, tabung reaksi, tabung Erlenmeyer, autoclave, gunting, spidol, dan sarung tangan.

Bahan-bahan yang digunakan dalam penelitian ini yaitu: spons laut Callypongia sp., bakteri Pseudomonas aeruginosa, bakteri Eschericia coli, kapas steril, MEA (Malt Extract Agar), alkohol 70\%, agar plain, akuades, NA (Nutrient Agar), BHI (Brain Heart Infusion), MHA (Mueller Hinton Agar).

\section{Isolasi Jamur Endosimbion}

Alat-alat yang digunakan dalam penelitian ini disterilkan dalam oven pada suhu $170^{\circ} \mathrm{C}$ selama \pm 1 jam (sterilisasi kering). Media disterilkan dalam autoclave pada suhu $121^{\circ} \mathrm{C}$ selama 15 menit (sterilisasi basah).Spons laut Callyspongia sp. diambil dan dibersihkan.Spons, pinset dan gunting direndam dalam larutan alkohol $70 \%$ selama 10 detik untuk menghindari kontaminasi dari bakteri.Spons lautdipotong berbetuk kecil.Potongan tersebut ditanam pada media agar yang dibuat dari MEA (Malt Extract Agar) dan Agar plain di dalam cawan petri. Kloramfenikol 0,2 g/ml sebelumnya ditambahkan ke dalam media agar untuk mencegah pertumbuhan bakteri lainnya. Cawan petri yang berisi spons laut tersebut ditutup, kemudian disimpan pada suhu kamar $\left(25^{\circ} \mathrm{C}\right)$ selama $2 \times 24$ jam untuk menumbuhkan jamur. Setelah 2x24 jam, akan terlihat pertumbuhan dari jamur di sekitar spons pada media agar. Setiap spons laut yang ditanam dapat menghasilkan beberapa pertumbuhan jamur endosimbion yang berbeda.

\section{Pemurnian Jamur Endosimbion}

Jamur endosimbion yang sudah tumbuh diambil sebagian dari miselia jamur tersebut pada permukaan agar 
dengan menggunakan kawat ose steril dan dipindahkan ke media MEA (Malt Extract Agar) lainnya dengan maksud untuk memurnikan pertumbuhan jamur endosimbion. Hal ini dilakukan pada setiap jamur endosimbion yang secara morfologi berbeda yang tumbuh pada spons laut tersebut. Pemurnian ini bertujuan untuk memisahkan koloni endosimbion dengan morfologi berbeda untuk dijadikan isolat tersendiri, disimpan pada suhu ruangan selama 2x24 jam.

\section{Penyiapan Media Agar Miring dan Bakteri Uji}

Nutrient Agar (NA) ditimbang sebanyak 2,3 gram dan dilarutkan dalam 100 ml akuades. Media kemudian disterilisasi dalam autoclave pada suhu $121^{\circ} \mathrm{C}$ selama 15 menit. Selanjutnya media dituang dalam tabung reaksi sebanyak $7 \mathrm{ml}$ dan dibiarkan mengeras dengan kemiringan $15^{\circ}$. Brain Heart Infusion (BHI) ditimbang sebanyak 3,7 gram kemudian dilarutkan dalam $100 \mathrm{ml}$ akuades. Media disterilisasi dengan autoclave pada suhu $121^{\circ} \mathrm{C}$ selama 15 menit.Media selanjutnya dituang ke tabung reaksi sebanyak $5 \mathrm{ml}$ untuk selanjutnya digunakan sebagai media suspensi bakteri. Bakteri yang dikultur pada agar miring diambil dengan kawat ose steril dan dimasukkan ke dalam media BHI. Suspensi bakteri kemudian digoreskan dengan kawat ose steril di permukaan media kombinasi. Jamur endosimbion yang telah tumbuh pada media MEA (Malt Extract Agar) kemudian dipotong membentuk bulat dan diletakkan pada media kombinasi MEA (Malt Extract Agar) dan MHA (Mueller Hinton Agar) yang telah digoresi bakteri uji.MHA ditimbang sebanyak 1,9 gram dan MEA ditimbang sebanyak 1,25 gram, selanjutnya dilarutkan dalam $100 \mathrm{ml}$ akuades. Media tersebut disterilisasi di autoclave dengan suhu $121^{\circ} \mathrm{C}$, kemudian tuang pada cawan petri, yang kemudian digunakan sebagai media kombinasi.
Uji Kemampuan Daya Hambat Jamur Endosimbion dan Pengukuran Zona Hambat

Penanaman jamur di media kombinasi MEA (Malt Extract Agar) dan MHA (Mueller Hinton Agar) dilakukan masingmasing 3 sampel jamur yang sama di 3 tempat pada 1 cawan petri. Sebagai kontrol positif diberikan larutan kloramfenikol 2 $\mathrm{mg} / \mathrm{ml}$ pada kertas saring dan diletakkan di tengah-tengah media, selanjutnya diinkubasi pada suhu kamar $\left(25^{\circ} \mathrm{C}\right)$. Setelah 24 jam dengan menggunakan penggaris milimeter dilakukan pengukuran diameter zona hambat, yaitu zona bening yang terbentuk di sekitar jamur endosimbion dan kertas saring.Pengukuran zona hambat dilakukan menggunakan penggaris dengan cara membalik cawan petri media kombinasi dan mengukur diameter daerah jernih.Terdapat daerah jernih di sekeliling media pertumbuhan bakteri uji yang tidak ditumbuhi bakteri.Diameter zona hambat diukur dalam satuan milimeter.

\section{HASIL PENELITIAN}

Jamur endosimbion mulai tumbuh dari potongan tubuh spons setelah diinkubasi selama 2 x 24 jam pada suhu ruang pada media MEA, setelah dilakukan proses pemurnian, diperoleh 2 jenis isolat dengan karakteristik berupa miselia berwarna hitam dan coklat.

Diameter zona hambat yang terbentuk dari kedua jamur endosimbion dapat dilihat pada Gambar 1.Pengukuran diameter zona hambat dapat dilihat pada Tabel 1 dan 2 berikut ini.

\section{BAHASAN}

Dari sampel spons yang diambil dari Pantai Malalayang diperoleh 2 isolat jamur endosimbion dengan karakteristik miselia yang berwarna hitam dan coklat.

Dari hasil uji daya hambat terhadap kedua jamur, didapatkan jamur hitam tidak memiliki zona hambat, dan jamur coklat memiliki zona hambat, diduga jamur coklat memiliki senyawa yang dapat menghambat pertumbuhan bakteri Pseudomonas aeruginosa dan Eschericia colinamun 
belum diketahui jenis senyawa antibakteri maupun mekanisme kerjanya.

Bila dibandingkan dengan zona hambat dari kontrol positif, maka hasil dari kontrol positif lebih besar daripada jamur coklat, faktor yang dapat mempengaruhi hal ini yakni minimal inhibitory consentration (MIC), yang mana konsentrasi dari kloramfenikol telah diketahui sedangkan pada jamur isolat aktif dari spons belum diketahui konsentrasi yang tepat untuk menghambat pertumbuhan bakteri Pseudomonas aeruginosa dan Eschericia coli.
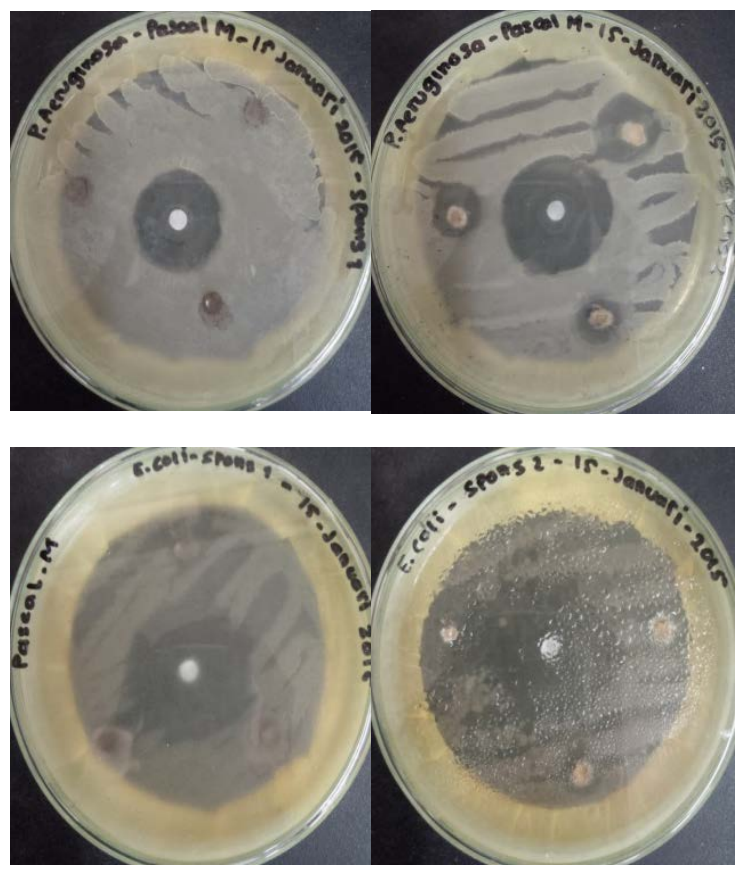

Gambar 1.Diameter zona hambat jamur endosimbion spons laut Callyspongia sp. terhadap bakteri Pseudomonas aeruginosa dan Eschericia coli

Tabel 1. Hasil uji jamur Endosimbion pada terhadap bakteri Pseudomonas aeruginosa

\begin{tabular}{|c|c|c|c|c|}
\hline \multirow{2}{*}{ Sampel } & \multirow{2}{*}{$\begin{array}{c}\text { Diameter jamur } \\
(\mathrm{mm})\end{array}$} & \multicolumn{2}{|c|}{ Diameter zona hambat (mm) } & \multirow{2}{*}{ Kontrol $(+)$} \\
\hline & & Jamur hitam & Jamur Coklat & \\
\hline 1 & 10 & 0 & 14,8 & $28,7 \mathrm{~mm}$ \\
\hline 2 & 10 & 0 & 20,9 & \\
\hline 3 & 10 & 0 & 14,9 & \\
\hline rata-rata & 10 & 0 & 16,8 & $28,7 \mathrm{~mm}$ \\
\hline
\end{tabular}

Tabel 2. Hasil uji jamur Endosimbion pada terhadap bakteri Eschericia coli

\begin{tabular}{|c|c|c|c|c|}
\hline \multirow{2}{*}{ Sampel } & \multirow{2}{*}{$\begin{array}{l}\text { Diameter jamur } \\
(\mathrm{mm})\end{array}$} & \multicolumn{2}{|c|}{ Diameter zona hambat (mm) } & \multirow{2}{*}{ Kontrol (+) } \\
\hline & & Jamur Hitam & Jamur Coklat & \\
\hline 1 & $10 \mathrm{~mm}$ & 0 & 24 & $38,2 \mathrm{~mm}$ \\
\hline 2 & $10 \mathrm{~mm}$ & 0 & 16,1 & \\
\hline 3 & $10 \mathrm{~mm}$ & 0 & 10,5 & \\
\hline rata-rata & $10 \mathrm{~mm}$ & 0 & 16,8 & $38,2 \mathrm{~mm}$ \\
\hline
\end{tabular}


Pada penelitian ini zona hambat yang terjadi pada jamur coklat hanya bersifat bakteriostatik, hal ini ditunjukkan setelah masa inkubasi 2 x 24 jam daerah jernih pada zona hambat mulai ditumbuhi bakteri. $^{2}$

\section{SIMPULAN}

Berdasarkan hasil penelitian dapat disimpulkan bahwa jamur endosimbion yang diisolasi dari spons laut Callyspongia sp. memiliki aktivitas menghambat pertumbuhan dari bakteri Pseudomonas aeruginosa dan Eschericia coli.

\section{SARAN}

1. Perlu dilakukan penelitian selanjutnya untuk mengetahui bagaimana mekanisme terjadinya zona hambat

2. Perlu dilakukan penelitian selanjutnya untuk mengetahui senyawa dari jamur Endosimbion spons laut Callyspongia sp. yang dapat menghambat pertumbuhan bakteri

3. Perlu dilakukan penelitian selanjutnya untuk mengetahui daya hambat dari jenis spons laut lain.

\section{DAFTAR PUSTAKA}

1. Suparno. Kajian bioaktif spons laut (porifera: demospongiae) suatu peluang alternatif pemanfaatan ekosistem karang indonesia dalam dibidang farmasi [Makalah]. Bandung: Institut Pertanian Bogor;2005.

2. Warbung YY, Wowor VNS dan Posangi J. Daya hambat ekstrak spons laut Callyspongiae sp. terhadap pertumbuhan Staphylococcus aereus. 2013.

3. Hanani E, Mun'im A dan Sekarini R. Identifikasi senyawa antioksidan dalam spons Callyspongia sp dari Kepulauan Seribu. Majalah Ilmu Kefarmasian. 2005;2:127-33.

4. Nurhayati T, Suhartono MT, Nuraida L dan Poerwanto SB. Karakterisasi awal inhibitor protase dari bakteri yang berasosiasi dengan spons asal Pulau Panggang, Kepulauan Seribu. Hayati. 2006;13:58-64.

5. Haedar $\mathbf{N}$ dan Purdian H. Bioaktivitas bakteri Chromohalobacter sp. dari Callyspongia sp. terhadap bakteri patogen. 2010.

6. Liwang F. Uji aktivitas antibakteri jamur endofit akar bakau Avicennia marina terhadap bakteri Staphylococus aureus dan Eschericia coli [skripsi]. Manado: Fakultas Kedokteran Universitas Sam Ratulangi; 2014.

7. Wuryanti dan Murnah. Uji ekstrak bawang bombay terhadap anti bakteri gram negatif Pseudomonas aeruginosa dengan metode cakram. Sains \& Matematika. 2009;17:151-8. 